\title{
EFEKTIVITAS PENGGUNAAN LEAFLET DAN BUKU SAKU TERHADAP PENGETAHUAN DAN SIKAP WUS TENTANG DETEKSI DINI KANKER SERVIKS
}

\author{
1.Pauline Kusmaryati \\ ${ }^{1.2}$ Jurusan Kebidanan Poltekkes Kemenkes Jambi \\ linealtila@yahoo.com
}

\begin{abstract}
Abstrak
Kanker serviks adalah tumor ganas yang tumbuh didalam leher rahim, yaitu bagian terendah dari leher rahim yang menempel pada puncak vagina. Di Puskesmas Payo Selincah Kota Jambi terdapat 2 kasus WUS (wanita usia subur) yang positif terkena kanker servik di tahun 2017. Ada beberapa faktor yang mempegaruhi rendahnya pemeriksaan deteksi dini kanker serviks, serta belum di ketahui media apa yang tepat untuk penyampaian dalam upaya deteksi dini kanker serviks. Penelitian ini dilakukan di Posyandu Anggrek 4 Kelurahan Eka Jaya Kota Jambi dengan tujuan untuk mengetahui efektivitas penggunaan leaflet dan buku saku terhadap pengetahuan dan sikap WUS tentang deteksi dini kanker serviks Penelitian ini merupakan semi eksperimen dengan pendekatan two group pretest-posttest. Populasi dalam penelitian ini adalah semua wanita usia subur di Posyandu Anggrek 4 Kelurahan Eka Jaya Kota Jambi. Pengambilan sampel menggunakan total sampling didapatkan 60 sampel. Pengumpulan data menggunakan lembar kuesioner dan penyuluhan pretest dan postest. Data yang diperoleh kemudian diolah dan dianalisa, analisa data mencangkup analisis univariat untuk mencari distribusi frekuensi dan analisis bivariat dengan Uji wilcoxon $(a=0,05)$ untuk mengetahui pengaruh antara variabel. Berdasarkan hasil penelitian didapatkan tidak ada perubahan yang signifikan antara pengetahuan $(\mathrm{p}=0,001)$ dan $\operatorname{sikap}(\mathrm{p}=1,000)$ sebelum dan sesudah diberikan leaflet. Ada perubahan yang signifikan antara pengetahuan $(\mathrm{p}=0,000)$ dan sikap $(\mathrm{p}=0,007)$ WUS sebelum dan sesudah diberikan buku saku., terdapat efektivitas penggunaan buku saku terhadap pengetahuan dan sikap tentang deteksi dini kanker serviks,sedangkan penggunaan leaflet kurang efektif terhadappeningkatan pengetahuan dan sikap tentang deteksi dini kanker serviks.
\end{abstract}

Kata kunci : Buku saku; Kanker Serviks; Leaflet,

Abstract
Cervical cancer is a malignant tumor that grows in the cervix, which is the lowest part of the cervix that attaches to the top of the vagina. In the Payo Selincah Health Center in Jambi City there were 2 cases of WUS (suburban age women) that were positive as cervical cancer in 2017. There are several factors that affect early examination of cervical cancer, and also in media that can be used for delivery in the search for cervical cancer early detection. This research was conducted at Anggrek 4 Posyandu in Eka Jaya Village, Jambi City with the aim of understanding the use of leaflets and pocket books on WUS's knowledge and attitudes about early detection of cervical cancer. This study was semi-experimental using two groups of pretest-posttest. The population in this study were all women of suburban age at Posyandu Anggrek 4, Eka Jaya Village, Jambi City. Sampling using total sampling obtained 60 samples. Data collection using questionnaire sheets and counseling pretest and posttest. The data obtained were then processed and analyzed, data analysis included univariate analysis to find frequency distribution and bivariate analysis with Wilcoxon Test $(a=0.05)$ to find out the relationship between variables. Based on the results of the study, there was no significant change between knowledge $(p=0.001)$ and attitude $(p=$ $1,000)$ before and given leaflets. There was a significant change between knowledge $(p=0,000)$ and attitude $(p=$ 0,007) WUS before and after being given a pocket book. It was necessary to use a pocket book on knowledge and attitudes about early detection of cervix, the use of leaflets was less effective in increasing knowledge and attitudes. about early detection of cervical cancer.

Keywords: Pocket Book; Cancer Cervix; Leaflets; 


\section{PENDAHULUAN}

Kanker serviks atau kanker leher rahim adalah tumor ganas yang tumbuh di dalam leher rahim, yaitu bagian terendah dari rahim yang menempel pada puncak vagina. Kanker serviks biasanya menyerang wanita usia 35- 55 tahun. Hampir 90\% dari kanker serviks berasal dari sel skuamosa yang melapisi serviks. Sedangkan $10 \%$ sisanya berasal dari sel kelenjar penghasil lendir pada saluran servikal yang menuju rahim (Kartikawati, 2013).

Berdasarkan data Riset Kesehatan Dasar (Riskesdas)prevalensi kanker di Indonesia adalah 4,1 per 1000 penduduk, atau sekitar 330.000 orang. Kanker tertinggi di Indonesia pada perempuan adalah kanker payudara dan kanker leher rahim (serviks). Berdasarkan estimasi IARC tahun 2012, insiden kanker payudara sebesar 40 per100.000 perempuan, kanker leher rahim 17 per 100.000 perempuan (Kemenkes,2014).

Dinas Kesehatan Provinsi Jambi mencatat 284 perempuan terdeteksi positif kanker serviks, dari 8.525 wanita menikah dengan usia subur atau rentang 30-50 tahun yang periksa melalui deteksi dini kanker kanker mulut rahim( serviks) diantara 284 positif. dari perempuan yang positif kanker serviks itu yang paling banyak terdapat di kota jambi dengan 102 orang positif yang kemudian Kabupaten Merangin dengan 50 orang positif kemudian diikuti masing-masing daerah dengan rata-rata puluhan yang positif (Profil Jambi, 2016).

Insiden kanker serviks sebenarnya dapat ditekan dengan melakukan upaya pencegahan primer seperti meningkatkan atau intensifikasi kegiatan penyuluhan kepada masyarakat untuk menjalankan pola hidup sehat, menghindari faktor resiko terkena kanker, melakukan imunisasi dengan vaksin HPV dan diikuti dengan deteksi dini kanker servik tersebut melalui pemeriksaan pap smear atau IVA atau paps smear (Rasjidi, 2009).

Penelitian yang dilakukan Ayu tentang Efektivitas Media Leaflet dan film terhadap pengetahuan dan tentang kanker serviks dan Partisipasi Wanita dalam deteksi dini kanker serviks di kampung Darek Kecamatan Padang
Sidempuan Selatan tahun 2015, disimpulkan adanya pengaruh efektivitas media leaflet terhadap peningkatan pengetahuan responden tentang kanker serviks.

Sikap seseorang tentang pencegahan kanker servik juga dapat menentukan perilakunya dalam melakukan deteksi dini, sikap merupakan reaksi tertutup yang sangat besar Efektivitasmya terhadap perilaku kesehatan.Hasil penelitian menunjukan semakin baik sikap seseorang maka semakin besar untuk melakukn perilaku kesehatan (Wawan, 2010).

Strategi pencegahan primer yang dapat dilakukan yaitu dengan pemberian pendidikan kesehatan tentang kanker serviks itu sendiri. Banyak metode yang dapat dilakukan untuk memberikan pendidikan kesehatan pada WUS (Wanita Usia Subur), misalnya melalui media film, video, ceramah, leaflet dan poster(Notoadmodjo, 2012).

Media yang dapat digunakan untuk memberikan pendidikan pada WUS (wanita usua subur), misalnya melalui Leaflet juga diartikan sebagai salah satu media yang enggunakan selembar kertas yang berisi tulisan cetak tentang suatu masalah khusus untuk sasaran yang dapat membaca dan biasanya di sajikan dalam bentuk lipatan yang dipergunakan untuk penyampaian informasi atau penguat pesan disampaikan (Notoatmodjo, 2012)

Leaflet yaitu lembaran kertas yang dilipat mengandung pesan tercetak sebagai informasi mengenai suatu hal atau peristiwa, yang berisi informasi berbentuk kalimat, gambar, ataupun kombinasi. Leaflet sebagai media atau alat bantu lihat (visual ald) dalam memberikan pendidikan menunjukan hasil yang lebih baik jika dibandingkan dengan memberikan pendidikan tanpa adanya penggunaan media. Ciri-ciri leaflet tulisan terdiri dari 200 sampai 400 huruf dengan tulisan cetak biasanya juga diselingi gambargambar, isi leaflet harus dibaca sekali pandang dan ukurann biasanya sampai dengan $\mathrm{cm}$ (Arif Sudirman, 2011).

Buku juga merupakan salah satu contoh media cetak dalam melakukan pendidikan. Salah 
satu jenis buku yang digunakan sebagai media dalam melakukan pendidikan adalah buku saku. Buku saku hampir sama dengan booklet, hanya saja berukuran lebih kecil sehingga bisa dimasukan ke dalam saku. Buku ini berisi tulisan dan gambargambar seperti buku, hanya saja isinya jauh lebih singkat dan jelas (Notoatmodjo, 2007).

Berdasarkan Data Dinas Kesehatan Kota Jambi tahun 2017 dari 20 Puskesmas yang ada di Kota Jambi, Puskesmas Payo Selincah termasuk yang rendah dalam pelaksanakan pemeriksaan Deteksi Dini pada bulan Januari s/d Desember berjumlah 17 orang (Depkes Kota Jambi, 2017).

\section{METODE PENELITIAN}

Jenis penelitian ini adalah kuasi eksperimen (quasi experimental) dengan rancangan pre-test-post-test group design (Sugiyono,2010: 160). Sampel dikelompokkan menjadi dua yaitu kelompok perlakuan dan kelompok pembanding. Pada kelompok perlakuan diberikan promosi kesehatan dengan menggunakan leaflet. Pada kelompok pembanding diberikan Buku saku. Dengan mengobservasi sebanyak 2 kali yaitu sebelum dan sesudah diberikan perlakuan. Kelompok diobservasi sebelum dilakukan intervensi, kemudian diobservasi kembali setelah intervensi di lain waktu yang telah ditentukan (Nursalam, 2013).

Populasi dalam penelitian ini adalah seluruh WUS yang mengikuti kegiatan di Posyandu Anggrek 4 di Kelurahan Eka Jaya tahun 2018 yang berjumlah 60 orang.Sampel pada penelitian ini adalah total populasi yang dibagi menjadi 2 kelompok masing-masing kelompok terdiri dari 30 orang.

Analisis data melalui analisis univariat bertujuan untuk mengetahui distribusi frekuensi atau proporsi masing-masing variabel yang diteliti, Analisis bivariat bertujuan untuk mempelajari anatara 2 variabel yaitu variabel independen dengan variabel dependen. Uji statistik Wilcoxon untuk mengetahui ada ada tidaknya perbedaan antara dua sampel dependen yang berpasangan atau berkaitan dan dugunakan sebagai alternatif penganti uji Paired $\mathrm{T}$ test jika data tidak berdistribusi normal

\section{HASIL DAN PEMBAHASAN}

\subsection{Hasil Analisis Univariat}

Pengukuran pengetahuan dikategorikan menjadi 2 yaitu baik jika skor jawaban $>76 \%$ dan kurang baik jika skor jawaban < 76\% untuk selengkapnya dapat dilihat pada diagram berikut ini :

Diagram 1

Gambaran Pengetahuan Wus

SebelumDiberikan Leaflet Tentang Deteksi

Dini Kanker Serviks Di Posyandu Anggrek

4Kelurahan Eka Jaya Kota Jambi

Pengetahuan Pre Test Leaflet

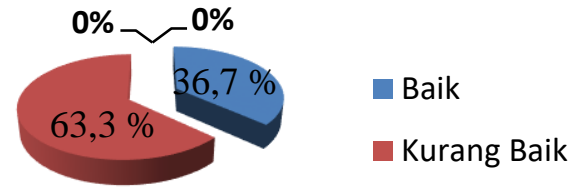

Bedasarkan diagram diatas, didapatkan $63,3 \%$ responden memiliki pengetahuan kurang baik tentang deteksi dini kanker serviks dan 36,7\% memiliki pengetahuan baik tentang deteksi dini kanker serviks. Pengukuran sikap dikategorikan menjadi 2 yaitu positif jika skor jawaban median > 36 dan negatif jika skor jawaban < 36 untuk selengkapnya dapat dilihat pada diagram berikut ini :

Diagram .2

Gambaran Sikap Wus SebelumDiberikan Leaflet TentangDeteksi Dini Kanker Erviks DiPosyandu Anggrek 4Kelurahan Eka Jaya Kota Jambi

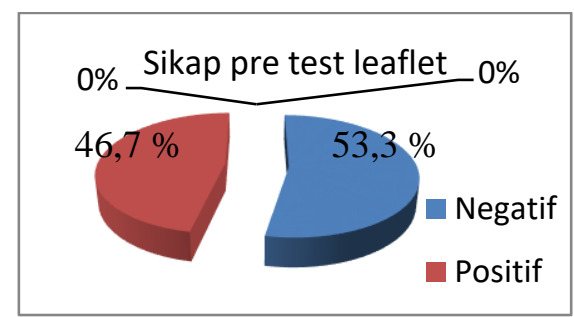


Berdasarkan diagram 5.2 didapatkan 46,7 \% responden memiliki sikap positif tentang deteksi dini kanker serviks dan 53,3\% memiliki sikap negatif tentang deteksi dini kanker serviks.

Dari hasil penelitian didapatkan hasil gambaran pengetahuan responden sesudah diberikan leaflet tentang deteksi dini kanker serviks di posyandu Anggrek 4 kelurahan Eka Jaya Kota Jambi tahun 2018. Adapun gambaran tersebut dapat dilihat pada diagram dibawah ini :

Diagram 3

Gambaran pengetahuan responden sesudah diberikan leaflettentang deteksi dini kanker serviks di posyanduAnggrek 4 Kelurahan Eka Jaya kota Jambi

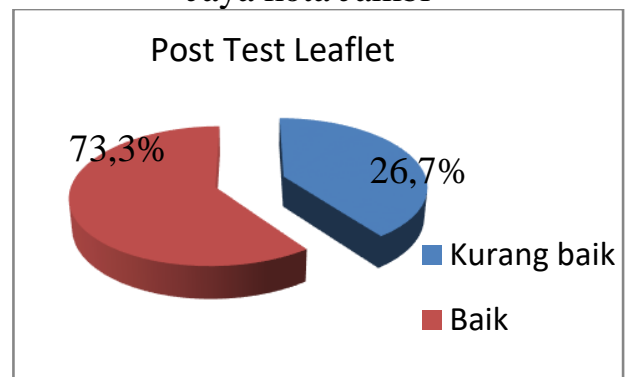

Berdasarkan diagram diatas didapatkan $26,7 \%$ responden memiliki pengetahuan kurang baik tentang deteksi dini kanker serviks dan 73,3\% memiliki pengetahuan baik tentang deteksi dini kanker serviks. Dari hasil penelitian didapatkan hasil gambaran pengetahuan responden sesudah diberikan buku saku tentang deteksi dini kanker serviks di posyandu Anggrek 4 kelurahan Eka Jaya Kota Jambi tahun 2018. Adapun gambaran tersebut dapat dilihat pada diagram dibawah ini :

Diagram 4

Gambaran pengetahuan respondensesudah diberikan buku sakutentang deteksi dini kanker serviks diposyandu Anggrek 4 kelurahan Eka Jaya kota Jambi

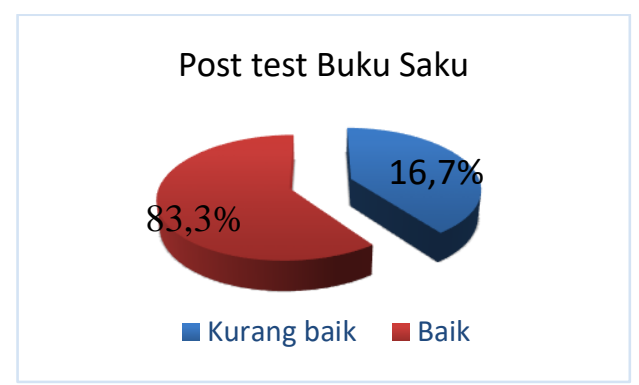

Berdasarkan diagram diatas didapatkan $16,7 \%$ responden memiliki pengetahuan kurang baik tentang deteksi dini kanker serviks dan 83,3\% memiliki pengetahuan baik tentang deteksi dini kanker serviks. Dari hasil penelitian didapatkan hasil gambaran sikap responden sesudah diberikan leaflet tentang deteksi dini kanker serviks di posyandu Anggrek 4 kelurahan Eka Jaya kota Jambi tahun 2018. Adapun gambaran tersebut dapat dilihat dapa diagram dibawah ini :

\section{Diagram 5}

Gambaran sikap responden sesudah diberikan leaflettentang deteksidini kanker serviks di posyanduanggrek 4 Kelurahan Eka Jaya Kota Jambi

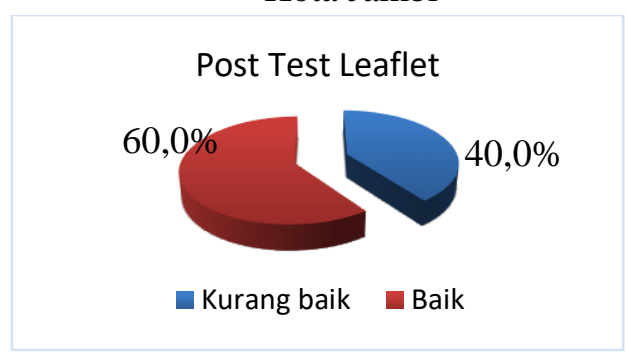

Berdasarkan diagram diatas, didapatkan $40,0 \%$ responden memiliki sikap negatif tentang deteksi dini kanker serviks dan 60,0\% memiliki sikappositif tentang deteksi dini kanker serviks.

Dari hasil penelitian didapatkan hasil gambaran sikap responden sesudah diberikan buku saku tentang deteksi dini kanker serviks di posyandu Anggrek 4 kelurahan Eka Jaya kota Jambi tahun 2018. Adapun gambaran tersebut dapat dilihat dapa diagram dibawah ini :

\section{Diagram 6}

Gambaran sikap responden sesudah diberikan buku saku tentang deteksi dini kanker serviks di posyanduAnggrek 4 kelurahan Eka Jaya kota Jambi

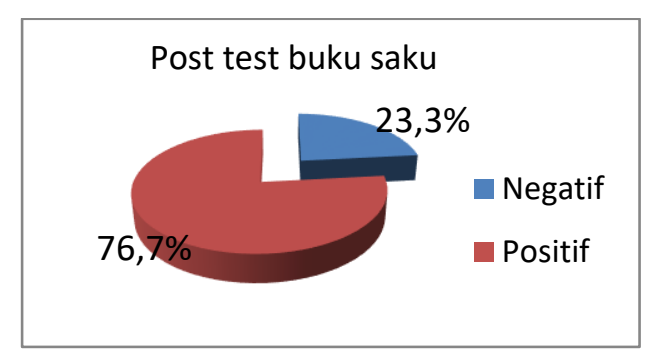


Berdasarkan diagram 5.6 didapatkan $23,3 \%$ responden memiliki sikapnegatif tentang deteksi dini kanker serviks dan 76,7\% memiliki sikap positif tentang deteksi dini kanker serviks.

\subsection{Analisis Bivariat}

Efektivitas penggunaan Leaflet terhadap pengetahuan dan sikap sebelum- sesudah pada WUS tentang deteksi dini kanker serviks di posyandu Anggrek 4 kelurahan Eka Jaya kota Jambi

Hasil penelitian diketahui pengetahuan sebelum dan sesudah diberikan leaflet $p=0,001<\mathrm{a}$ $=0,05$ terdapat perbedaan antara kelompok sebelum dan sesudah. Sedangkan sikap sebelum dan sesudah diberikan leaflet $p=1,000>\mathrm{a}=0,05$ tidak ada perbedaan antara sebelum dan sesudah diberikan leaflet. Hasil yang didapat dari uji wilcoxon adalah tidak ada perubahan yang signifikan diantara pengetahuan dan sikap sebelum dan sesudah diberikan leaflet.

\section{Tabel 1}

Perbandingan rerata penggunaan buku saku pengetahuan dan sikap terhadap WUS di posyandu Anggrek 4 kelurahan Eka Jaya kota Jambitahun 2018

\begin{tabular}{|c|c|c|c|c|c|c|}
\hline \multicolumn{7}{|c|}{$\mathrm{n}=(30)$} \\
\hline \multirow{2}{*}{$\begin{array}{c}\text { No } \\
\text {. }\end{array}$} & \multirow[t]{2}{*}{ Variabel } & \multicolumn{2}{|c|}{ Pre $(n=30)$} & \multicolumn{2}{|c|}{$\begin{array}{c}\text { Post } \\
(\mathrm{n}-30)\end{array}$} & \multirow[t]{2}{*}{ p-value } \\
\hline & & $\mathrm{N}$ & $\%$ & $\mathrm{~N}$ & $\%$ & \\
\hline \multirow[t]{3}{*}{1.} & Pengetahuan & & & & & \multirow{3}{*}{0,000} \\
\hline & Kurang baik & 21 & 70,0 & 5 & 16,7 & \\
\hline & Baik & 9 & 30,0 & 25 & 83,3 & \\
\hline \multirow[t]{3}{*}{2.} & Sikap & & & & & \multirow{3}{*}{0,007} \\
\hline & Kurang baik & 16 & 53,3 & 7 & 23,3 & \\
\hline & Baik & 14 & 46,7 & 23 & 76,7 & \\
\hline
\end{tabular}

Berdasarkan tabel diatas diketahui pengetahuan sebelum dan sesudah diberikan buku saku $p=0,000<\mathrm{a}=0,05$ terdapat perbedaan antara kelompok sebelum dan sesudah. Sedangkan sikap sebelum dan sesudah diberikan buku sakut $p=$ $0,007<\mathrm{a}=0,05$ terdapat perbedaan sebelum dan sesudah diberikan buku saku. Hasil yang didapat dari uji wilcoxon adalah adanya perubahan yang signifikan terhadap pengetahuan dan sikap sebelum dan setelah diberikan buku saku.

\subsection{Pembahasan}

3.3.1 Efektivitas penggunaan leaflet dan buku saku terhadap pengetahuan pada WUS tentang deteksi dini kanker serviks.

Hasil analisis pengetahuan pada kelompok leaflet (post test) sebesar $p=0,001$ $<\mathrm{a}=0,05$ sedangkan pengetahuan kelompok media buku saku setelah diberikan penyuluhan (post test) $p=0,001<\mathrm{a}=0,05$. Dari hasil uji tersebut diperoleh adanya perbedaan yang bermakna dan signifikan terhadap pengetahuan post test grup leaflet dan post test grup buku saku.Media buku saku lebih efektif terhadap peningkatan pengetahuan WUS dalam deteksi dini kanker serviks.

Pengetahuan dapat bertambah atau meningkat dengan adanya informasi dengan menggunakan berbagai macam media yaitu media cetak dan media elektronik, adapun media cetak itu antara lain : poster, leaflet,brosur, majalah, surat kabar, dan stiker.Untuk media cetak misalnya : televisi, radio dan tape recorder,vcd dan video.

Hasil penelitian Mulidah (2010:62) tentang pengaruh media booklet dan leaflet. terhadap skor pengetahuan remaja putri tentang Dismenorhe di SMP Kristen 01 Purwokerto, menunjukan pengetahuan lebih baik setelah menerima media booklet dan leaflet.

Hasil penelitian ini juga diperkuat penelitian Muslikha dan Purwanti (2011:78) tentang peran leaflet ASI Ekslusif terhadap pengetahuan dan motivasi untuk menyusui secara Eksklusif BPS NY. Djuwedah Kebasen Kabupaten Banyumas, yang menunjukkan bahwa leaflet memiliki peran dalam peningkatkan pengetahuan ibu tentang ASI ekslusifdan motivasi ibu untuk menyusi secara Eksklusif 


\subsubsection{Efektivitas Penggunaan Leaflet dan Buku Saku terhadap sikap pada WUS tentang deteksi dini kanker serviks.}

Hasil analisis pengetahuan pada kelompok leaflet (post test) sebesar $p=1,000$ $<\mathrm{a}=0,05$ sedangkan pengetahuan kelompok media buku saku setelah diberikan penyuluhan (post test) $p=0,001<\mathrm{a}=0,007$. Hasil uji tersebut diperoleh adanya perbedaan yang bermakna secara signifikan terhadap pengetahuan post test grup leaflet dan post test grup buku saku dengan hasil media buku saku lebih efektif meningkatkan sikap positif WUS dalam deteksi dini kanker serviks.

Menurut Rizki Mahanani (2016:46) pengaruh pendidikan kesehatan menggunakan media booklet dan leaflet terhadap tingkat pengetahuan dan sikap WUS dalam melakukan pemeriksaan deteksi dini di Desa Pabelan dengan hasil penelitian sikap WUS mengenai pemeriksaan deteksi dini sebelum diberikan pendidikan kesehatan dalam kategori kurang dan sesudah diberikan pendidikan kesehatan meningkat menjadi baik. Terdapat pengaruh yang signifikan pendidikan kesehatan terhadap sikap WUS dalam melakukan pemeriksaan deteksi dini kanker serviks sebesar $p=0,001<0,05$.

Hasil ini sejalan dengan penelitian yang dilakukan Andini Ania Sari (2014:56) tentang pengaruh penyuluhan kanker serviks terhadap pengetahuan dan sikap ibu melakukan Deteksi dini Inspeksi Visual Asam Asetat di Dukuh Dermojurang, Pundog Bantul Yogyakarta 2014, hasil penelitian tentang sikap melakukan deteksi dini Inspeksi Visual Asam Asetat sebagian besar kategori cukup, yaitu 26 responden $(80,9 \%)$ dan yang paling sedikit mempunyai sikap kurang tentang deteksi dini inspeksi visual asam asetat yaitu 9 responden $(19,1 \%)$. Sedangkan setelah penyuluhan pengetahuan WUS tentang deteksi dini inspeksi visual asam asetat sebagian besar kategori baik yaitu 26 responden $(55,3 \%)$ dan yang paling sedikit mempunyai pengetahuan yang cukup untuk melakukan deteksi dini inspeksi visual asam asetat yaitu 21 responden $(44,7 \%)$.

\section{KESIMPULAN}

Sebelum diberikan leaflet dan buku saku, sebagian besar (63,3\%) WUS memiliki pengetahuan kurang baik tentang deteksi dini kanker serviks dan sebagian kecil $(36,7 \%)$ memiliki pengetahuan baik tentang deteksi dini kanker serviks.

Sebelum diberikan leaflet dan buku saku sebagian kecil (46,7\%) WUS memiliki sikap positif tentang deteksi dini kanker serviks dan sebagian besar(53,3\%)memiliki sikap negatif tentang deteksi dini kanker serviks.

Setelah diberikan leaflet sebagian kecil $(26,7 \%)$ WUS memiliki pengetahuan kurang baik tentang deteksi dini kanker serviks dan sebagian besar $(73,3 \%)$ memiliki pengetahuan baik tentang deteksi dini kanker serviks.

\section{UCAPAN TERIMA KASIH}

Ucapan terima kasih disampaikan kepada seluruh staf dan karyawan Posyandu Angrek, Tokoh masyarakat yang membantu dalam kelancaran penelitian ini.

\section{DAFTAR PUSTAKA}

[1] Kartikawati. Waspadai Kanker Pada Wanita. Yogyakarta : Andi Offset. VI+150hlm; 2013.

[2] Kemenkes RI,. Riset Kesehatan Dasar Tahun 2013. Jakarta; 2014.

[3] Dinkes Jambi. Data Kanker di Kota Jambi. Dinas Kesehatan Kota Jambi; 2016.

[4] Rasjidi. Deteksi Dini dan Pencegahan Kanker pada Wanita. Jakarta : Sagung Seto. Xii + 326 hlm; 2009.

[5] Wawan dan Dewi, Teori dan Pengukuran Pengetahuan, Sikap dan Perilaku Manusia. Yogyakarta : Nuha Medika. Viii+94 hlm; 2010. 
[6] Notoadmodjo S, Promosi Kesehatan dan Perilaku Kesehatan. Jakarta : Rineka Cipta. Vii+218 hlm; 2012.

[7] Arief S. Media Pendidikan. Jakarta : Gravindo Persada. xiv + 284 hlm; 2011

[8] Notoadmodjo S. Ilmu Perilaku Kesehatan. Jakarta : Rineka Cipta. Xii+269 hlm; 2007

[9] Dinkes Jambi. Data Deteksi Dini Kanker Payudara dan Kanker Leher Rahim di Kota Jambi. Dinas Kesehatan Kota Jambi; 2017 